\section{E-031 ENDOVASCULAR TREATMENT OF CEREBRAL ANEURYSMS USING LVIS JR STENT: MID-TERM CLINICAL AND ANGIOGRAPHIC RESULTS}

B Pabon*, C Diaz, O Vargas, J Mejia, N Serna, M Patiño. Neuroendovascular Surgery, angioteam - Clinica del Norte, Medellin, Colombia

\subsection{6/neurintsurg-2019-SNIS.106}

Purpose This report details our experience with the Low-profile Visualized Intraluminal Support Junior (LVIS Jr.) device (MicroVention-Terumo, Inc., Tustin, CA), with an emphasis on evolving treatment strategies, feasibility, complication rates and outcomes.

Methods We retrospectively reviewed records of patients treated with the LVIS Jr. device for intracranial aneurysms in Medellin, Colombia.

Results 254 patients with 279 aneurysms underwent aneurysm treatment with LVIS Jr during a 36-month study period. Stent deployment was successful in $100 \%$ of cases. 224 aneurysms were treated with stent-assisted coil embolization resulting in immediate complete occlusion in $90 \%$ of cases. 55 lesions were treated with stent-alone approach: 21 dissecting, blood blister-like aneurysms treated without coils, and 34 small aneurysms which treatment was planned in stages with further coiling after endothelization. Imaging follow-up was available for 104 aneurysms. None major recanalization for retreatment was observed. Seventeen patients presented with immediate thrombo-embolic complications (6.6\%) and IIb-IIIa GPI administration was necessary. Eight of these strokes were associated with transient deficits, yielding a stroke rate of $3.1 \%$. Six patients died $(2.4 \%)$ due to clinical conditions, not as direct consequence of stenting. No significant in-stent stenosis, migration, delayed hemorrhage, or permanent deficits were observed. Of those patients with follow-up, a good functional outcome based on the modified Rankin Scale score $(m R S \leq 2)$ was achieved in $100 \%$ of cases.

Conclusion LVIS Jr. facilitates the endovascular treatment of complex and wide necked cerebral aneurysms especially for aneurysms involving distal and small vessels. Results are promising in a variety of situations with safety and low rates of complications. Patients with acute $\mathrm{SAH}$ due to dissecting or wide-neck ruptured aneurysms can be treated under special considerations.

Disclosures B. Pabon: 2; C; Microvention, Medtronic, Stryker. C. Diaz: None. O. Vargas: None. J. Mejia: None. N. Serna: None. M. Patiño: None.

\section{E-032 ENDOVASCULAR THERAPY OF ANTERIOR COMMUNICATING ARTERY MICRO-ANEURYSMS: OUTCOMES AND COMPLICATION RATES - DATA FROM THE SMART REGISTRY}

E Almallouhi*, M Sattur, S Al Kasab, M Anadani, A Spiotta. Medical University of South Carolina, Charleston, SC

\subsection{6/neurintsurg-2019-SNIS. 107}

Background Previous studies have suggested that anterior communicating artery (ACoA) microaneurysms $(<4 \mathrm{~mm})$ were associated with a higher rate of peri-procedure complications when compared to ACoA aneurysms that were $4 \mathrm{~mm}$ or larger. We aimed to evaluate the outcomes of patients with unruptured ACoA aneurysms according to aneurysm size in a large, contemporary registry.

Methods We reviewed the prospective, multicenter SMART registry to identify patients with unruptured ACoA aneurysm who were treated with endovascular embolization using the SMART coils. We aimed to report the angiographic outcome and peri-procedural complications of endovascular embolization of ACoA aneurysm according to the aneurysm size $(<4$ mm vs. $\geq 4 \mathrm{~mm}$ ).

Results Out of 906 patients included in the SMART registry, $146(16.1 \%)$ patients had unruptured ACoA aneurysms (age $60.8 \pm 11.9 \mathrm{yr}$ and $61.6 \%$ were females). Of those ACoA, 43 were $<4 \mathrm{~mm}$ (micro-aneurysms). Microaneurysms were more likely to be wide-necked $(84.6 \%$ vs. $54.2 \%$, P 0.016$)$. No difference was found in the rate of peri-procedural device related adverse effects, periprocedural mortality, rate of adequate occlusion immediately and at one-year, length of hospitalization and one-year recanalization rate between both groups (table 1).

\begin{tabular}{|c|c|c|c|}
\hline Baseline Characteristics & $\begin{array}{l}\text { ACom Patients with } \\
\text { Aneurysm Size } 4 \mathrm{~mm} \\
(\mathrm{~N}=120)\end{array}$ & $\begin{array}{l}\text { ACom Patients with } \\
\text { Aneurysm Size }<4 \\
\mathrm{~mm} \\
(\mathrm{~N}=26)\end{array}$ & P-value \\
\hline Age, Mean SD & 61.311 .6 & 5813.4 & 0.207 \\
\hline Female, $\%(n / N)$ & $62.5 \%(75 / 120)$ & $57.7 \%(15 / 26)$ & 0.648 \\
\hline Aneurysm size $\%(\mathrm{n} / \mathrm{N})$ & & & 0.244 \\
\hline Small (<11 mm) & $95 \%(114 / 120)$ & $100.0 \%(26 / 26)$ & \\
\hline Large (11 to $25 \mathrm{~mm}$ ) & $5 \%(6 / 120)$ & $0.0 \%(0 / 26)$ & \\
\hline Giant $(>25 \mathrm{~mm})$ & $0.0 \%(0 / 120)$ & $0.0 \%(0 / 26)$ & \\
\hline Wide-Neck\% (n/N) & $54.2 \%(65 / 120)$ & $84.6 \%(22 / 26)$ & 0.016 \\
\hline $\begin{array}{l}\text { Time of Coil Deployment, } \\
\text { Minutes, Median [IQR] }\end{array}$ & $20[11$ to 34$]$ & $8[4.5$ to 15$]$ & $<0.001$ \\
\hline Stent-Assisted Coiling\% (n/N) & $57.5 \%(69 / 120)$ & $50 \%(13 / 26)$ & 0.485 \\
\hline $\begin{array}{l}\text { Balloon-Assisted Coiling } \% \\
(\mathrm{n} / \mathrm{N})\end{array}$ & $9.2 \%(11 / 120)$ & $15.4 \%(4 / 26)$ & 0.344 \\
\hline Raymond Class I & & & \\
\hline $\begin{array}{l}\text {-Immediate Post-Procedure\% } \\
(\mathrm{n} / \mathrm{N})\end{array}$ & $50 \%(60 / 120)$ & $57.7 \%(15 / 26)$ & 0.477 \\
\hline -One-Year Follow-Up\% (n/N) & $70.1 \%(47 / 67)$ & $86.7 \%(13 / 15)$ & 0.192 \\
\hline $\begin{array}{l}\text { Recanalization at One-Year } \\
\text { Follow-Up\% (n/N) }\end{array}$ & $13.4 \%(9 / 67)$ & $13.4 \%(2 / 15)$ & 0.985 \\
\hline $\begin{array}{l}\text { Retreatment through One- } \\
\text { Year Follow-Up }\end{array}$ & $4.4 \%(3 / 68)$ & $6.7 \%(1 / 15)$ & 0.929 \\
\hline Peri-procedural Mortality & $2.5 \%(3 / 120)$ & $2.3 \%(1 / 43)$ & 0.209 \\
\hline $\begin{array}{l}\text { Device-Related SAE within } \\
24 \text { Hours of Procedure\% ( } \mathrm{n} / \\
\text { N) }\end{array}$ & $5 \%(6 / 120)$ & $11.5 \%(3 / 26)$ & 0.415 \\
\hline $\begin{array}{l}\text { Length of Hospital Stay, } \\
\text { Median [IQR] }\end{array}$ & $1[1$ to 1$]$ & 1 [1 to 2$]$ & 0.76 \\
\hline
\end{tabular}

Conclusions Endovascular treatment of unruptured ACoA microaneurysms is associated with similar successful embolization and complication rates compared to larger size ACoA aneurysms.

Disclosures E. Almallouhi: None. M. Sattur: None. S. Al kasab: None. M. Anadani: None. A. Spiotta: 2; C; Penumbra, Cerenovus, Minnetronix. 